\title{
KDR Gene Amplification
}

National Cancer Institute

\section{Source}

National Cancer Institute. KDR Gene Amplification. NCI Thesaurus. Code C129613.

A molecular genetic abnormality indicating the presence of multiple copies of the KDR gene. 